\title{
Kinetics of serological responses in influenza A(H7N9)- infected patients correlate with clinical outcome in China, 2013
}

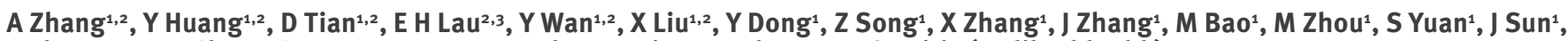

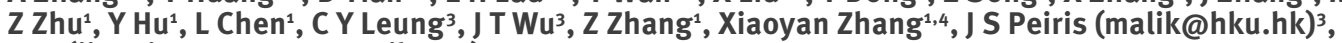

J Xu (jianqingxu2008@gmail.com) 1,4

1. Shanghai Public Health Clinical Center and Institutes of Biomedical Sciences, Key Laboratory of Medical Molecular Virology of Ministry of Education/Health, Shanghai Medical College, Fudan University, Shanghai, China

2. These authors equally contributed to this work

3. School of Public Health, The University of Hong Kong, Hong Kong, China

4. State Key Laboratory for Infectious Disease Prevention and Control, China CDC, Beijing, China

Citation style for this article:

Zhang A, Huang Y, Tian D, Lau EH, Wan Y, Liu X, Dong Y, Song Z, Zhang X, Zhang J, Bao M, Zhou M, Yuan S, Sun J, Zhu Z, Hu Y, Chen L, Leung CY, Wu JT, Zhang Z, Zhang X, Peiris JS, Xu J. Kinetics of serological responses in influenza A(H7N9)-infected patients correlate with clinical outcome in China, 2013. Euro Surveill. 2013;18(50): pii=20657. Available online: http://www.eurosurveillance.org/ViewArticle.aspx?Articleld=20657

Article submitted on 11 November 2013 / published on 12 December 2013

The novel avian influenza $\mathrm{A}(\mathrm{H} 7 \mathrm{~N} 9)$ infection has recently emerged to cause severe respiratory illness in China. The objectives of this study were to define the kinetics of the antibody responses in patients with influenza $\mathrm{A}\left(\mathrm{H}_{7} \mathrm{N9}\right)$ disease and to correlate these kinetics with clinical outcome. Serial serum samples were obtained at intervals of three to four days from 18 patients with virologically confirmed $\mathrm{A}\left(\mathrm{H}_{7} \mathrm{~N} 9\right)$ disease in Shanghai. We determined the kinetics of the haemagglutination inhibition $(\mathrm{HI})$ and $\mathrm{A}\left(\mathrm{H}_{7} \mathrm{H}_{9}\right)$ pseudotype neutralisation antibody ( $\mathrm{Nab}$ ) responses and correlated these with clinical outcomes. Most patients had robust serological responses by both $\mathrm{HI}$ and $\mathrm{Nab}$ tests. Taking into account censoring due to time of testing and death, the median time from onset of illness to Nab titre $\geq 1: 40$ was 14 days ( $95 \%$ confidence interval (Cl): 11-18 days) in the fatal cases and 10.5 days (95\% Cl: $7-12)$ in the survivors $(p=0.003)$. The two groups did not differ in initial Nab titres, but the rate of increase in Nab titres was significantly faster for survivors by approximately 10-fold per 15 days $(p=0.007)$. Early and rapid induction of Nab was correlated significantly with better clinical outcome.

\section{Introduction}

A novel avian influenza $\mathrm{A}\left(\mathrm{H}_{7} \mathrm{~N} 9\right)$ infection emerged to cause an outbreak in the Yangtze River delta in early 2013, subsequently spreading to other provinces in China [1-4]. In the first wave of influenza $A\left(\mathrm{H}_{7} \mathrm{~N} 9\right)$ infections from February to July 2013, 135 patients were reported from 11 provinces and municipalities in China, leading to 45 deaths [5]. Further cases have been reported since October 2013. Genomic analysis revealed that the novel $\mathrm{H}_{7}$ haemagglutinin is genetically distinct from other historical and contemporary human influenza viruses [3,6]. Adverse clinical outcomes have been associated with co-existing medical conditions or the development of drug resistance $[7,8]$. Previous
H7 subtype influenza virus infections in humans such as the influenza $\mathrm{A}\left(\mathrm{H}_{7} \mathrm{~N}_{7}\right)$ outbreak in Netherlands in 2003 were poorly immunogenic and serodiagnosis and seroepidemiology were challenging [9]. We explored the kinetics of the serological responses to this novel virus in haemagglutination inhibition (HI) assays and in a recently developed $\mathrm{H}_{7} \mathrm{~N} 9$ pseudotype virus particle neutralisation ( $\mathrm{Nab}$ ) test [10]. Viral pseudotypes have been previously shown to provide reliable correlation with conventional microneutralisation tests for influenza $A\left(\mathrm{H}_{5} \mathrm{~N}_{1}\right)$ serological studies [11]. We investigated correlations between serological responses and clinical outcome.

\section{Methods}

Patients and samples

In April 2013, 18 patients confirmed with influenza $A\left(\mathrm{H}_{7} \mathrm{~N} 9\right)$ infection by real-time PCR were hospitalised at the Shanghai Public Health Clinical Center (SHAPHC). Serum specimens were collected every three to four days following admission with two to seven serial serum samples being collected from each patient. Clinical data including patient demographic information, treatment, clinical investigations and disease progression were retrieved from the clinical notes. Written informed consent was obtained from all participants. The overall study was reviewed and approved by the Ethics Committee of SHAPHC.

\section{Haemagglutination inhibition assay}

The methods used were as previously described and used horse erythrocytes [12]. Serum samples were treated with receptor-destroying enzyme (RDE) (Denka Seiken Co Ltd., Tokyo, Japan) to remove non-specific inhibitors. Stored serum samples collected in 2009 from individuals not infected with influenza were used as negative serum controls. The virus strain used was 
A/Shanghai/4664T/2013 (H7N9) (GenBank accession No: KC853228.1).

\section{Pseudovirus-based neutralisation assay}

To rapidly and safely assess neutralisation activities against the 2013 influenza $\mathrm{A}\left(\mathrm{H}_{7} \mathrm{~N} 9\right)$ virus which caused severe disease in humans, we developed a luciferase reporter-based Nab assay which has a non-replicative human immunodeficiency virus backbone carrying influenza $\mathrm{A} \mathrm{H}_{7}$ and $\mathrm{H}_{9}$. We have previously demonstrated that the titres quantified by Nab assay correlated well with the titres measured by traditional $\mathrm{HI}$ assay, using serum samples from influenza $A\left(\mathrm{H}_{7} \mathrm{~N} 9\right)$ infected patients and uninfected subjects with good correlation (Spearman $r=0.88$ ) [10]. The pseudoviruses were prepared as described in our previous report [10]. The neutralising titre of human sera was defined as the highest serum dilution that gave $\geq 80 \%$ inhibitory concentration (IC80) of the luciferase signal in virus-infected MDCK cells. On the basis of previous studies we had defined that IC 80 and a antibody titre of 1:40 were the best discriminators between patients and non-infected controls, and we employed these to define positive Nab responses.

\section{Statistical analyses}

Non-parametric Mann-Whitney test was used to test the differences in $\mathrm{HI}$ or Nab titres across groups. Categorical variables were compared by using the twotailed Fisher's exact test to account for small sample size. In addition, univariate and multivariate exact logistic regression modelling were employed to identify the association of different factors with clinical outcome and allow for small cell size. The covariates used in the multivariate model included age, sex and NAb titres (1:40 and 1:640). The results were presented using odds ratios (ORs).

We fitted accelerated failure time model assuming a Gaussian distribution to compare time from illness onset to reaching a Nab titre of 1:40 between patients who recovered versus those who died, accounting for interval censoring due to time of testing. The model was also used to identify factors associated with longer time to recovery for recovered patients. We compared the initial Nab titre and rate of increase in Nab titre, adjusted for age and sex, using a linear mixed model to account for repeated measurements, assuming a linear increasing trend by days since illness onset. For analyses based on continuous measurements, titres were first log-transformed (with base 10). We used bootstrap method with 1,000 resamples to test the difference in time from illness onset to reaching a Nab titre of 1:40 between fatal cases and survivors. All statistical tests were considered significant at the level of pro.05. All data were analysed by using SPSS software (version 17.0) and $R$ (version 3.0.1).

\section{Results}

To understand the kinetics of the human serological responses to the novel influenza $A\left(\mathrm{H}_{7} \mathrm{~N} 9\right)$ virus, we first determined (HI) antibody and pseudotype $\mathrm{Nab}$ responses in 18 influenza $A\left(\mathrm{H}_{7} \mathrm{Ng}\right)$-infected patients. $\mathrm{HI}$ antibody titres reached a titre of 1:40 in six of 14 patients by Day 10 of illness. By Day 18 of illness, 17 of 18 patients had antibody titres of 1:40 with titres ranging from <1:10 to $1: 320$, and 10 of 18 patients had titres $\geq 1: 80$. All patients had evidence of seroconversion within three weeks (Figure). We next examined Nab titres quantified by the Nab assay. Nab titres reached 1:40 in five of 14 patients by Day 10 of illness and 16 of 17 by Day 18 of illness. Thirty-seven control sera collected in 2009 had negative results in both tests. To test the reliability of assays, limited repeat testing has been done on sets of sera by both assays with good reproducibility; in addition, all the sera were tested in one large assay batch to maintain comparability.

We examined the association between $\mathrm{HI}$ and $\mathrm{Nab}$ responses with clinical outcomes. The 18 patients were divided into two groups: group $A$ were 12 patients who recovered and group $B$ were six patients who had died (Table 1). The differences in $\mathrm{HI}$ titres between the two groups were not statistically significant. We next examined the development of $\mathrm{Nab}$ in the two patient groups, taking into account censoring due to time of testing and death. The median time from symptom onset to Nab titres reaching 1:40 was 10.5 days (95\% confidence interval ( $\mathrm{Cl}):$ 7-12 days) for patients who survived and 14.0 days ( $95 \% \mathrm{Cl}: 11-18$ days) for those who died. In patients who survived, it took a significantly shorter time to reach Nab titres of 1:40 for the unadjusted model ( $p<0.001$ ) and the model adjusted for age and sex ( $p<0.001)$. Adjusted for age and sex, there was no significant difference $(p=0.36)$ in the initial Nab titre between patients who survived and those who died. However, the Nab titre for survived patients increased significantly faster than for patients who eventually died, by approximately 10 -fold per 15 days $(p=0.007)$. The difference persisted when we restricted the analysis to patients with low initial Nab titres $(\leq 1: 40$ on day $10, p=0.003$ ).

We further examined the association between clinical outcome and sex, age, underlying medical disorders, timing for initiating antiviral treatment with oseltamivir or anti-inflammatory treatment with methylprednisolone and initial viral loads. None of these factors were significantly associated with clinical outcomes in the univariate analysis (Table 2). Nab titres reaching $\geq 1: 640$ or reaching $1: 40$ within 14 days were associated with survival in both univariate and multivariate analysis (Table 2). However, $\mathrm{HI}$ titres reaching 1:40 within 10 days were not associated with survival.

We also examined the association of these different factors with time to recovery in the survivors. Reaching Nab titres 1:640 within 14 days after illness onset was significantly associated with faster recovery $(p=0.002)$ in the univariate analysis (Table 3). After adjusting for other confounding factors, it was associated with a $22 \%$ shorter recovery time, although the effect was not 


\section{FIGURE}

Antibody responses in influenza A (H7N9) patients after illness onset, China, 2013 (n=18)

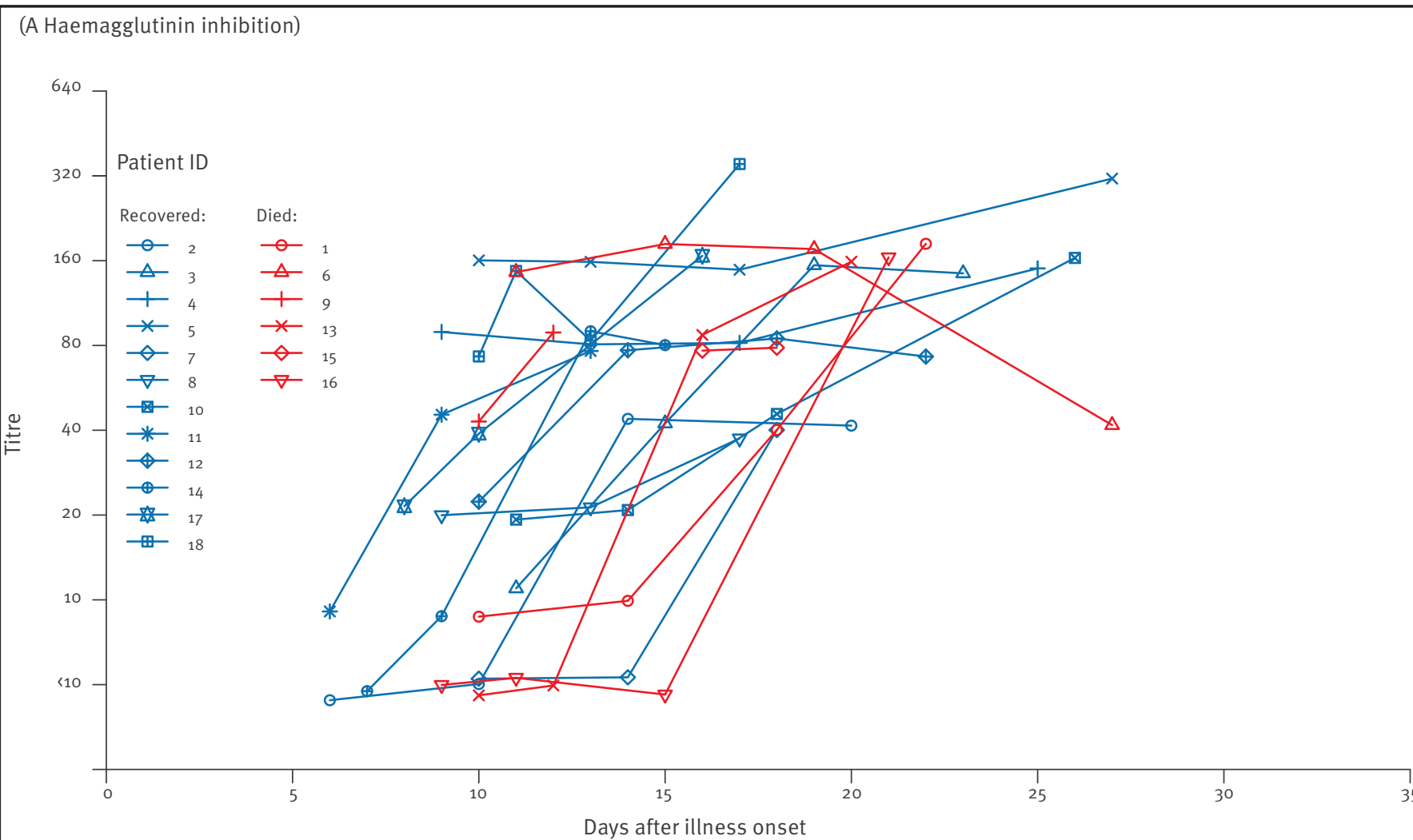

(B Pseudovirus-based neutralisation)

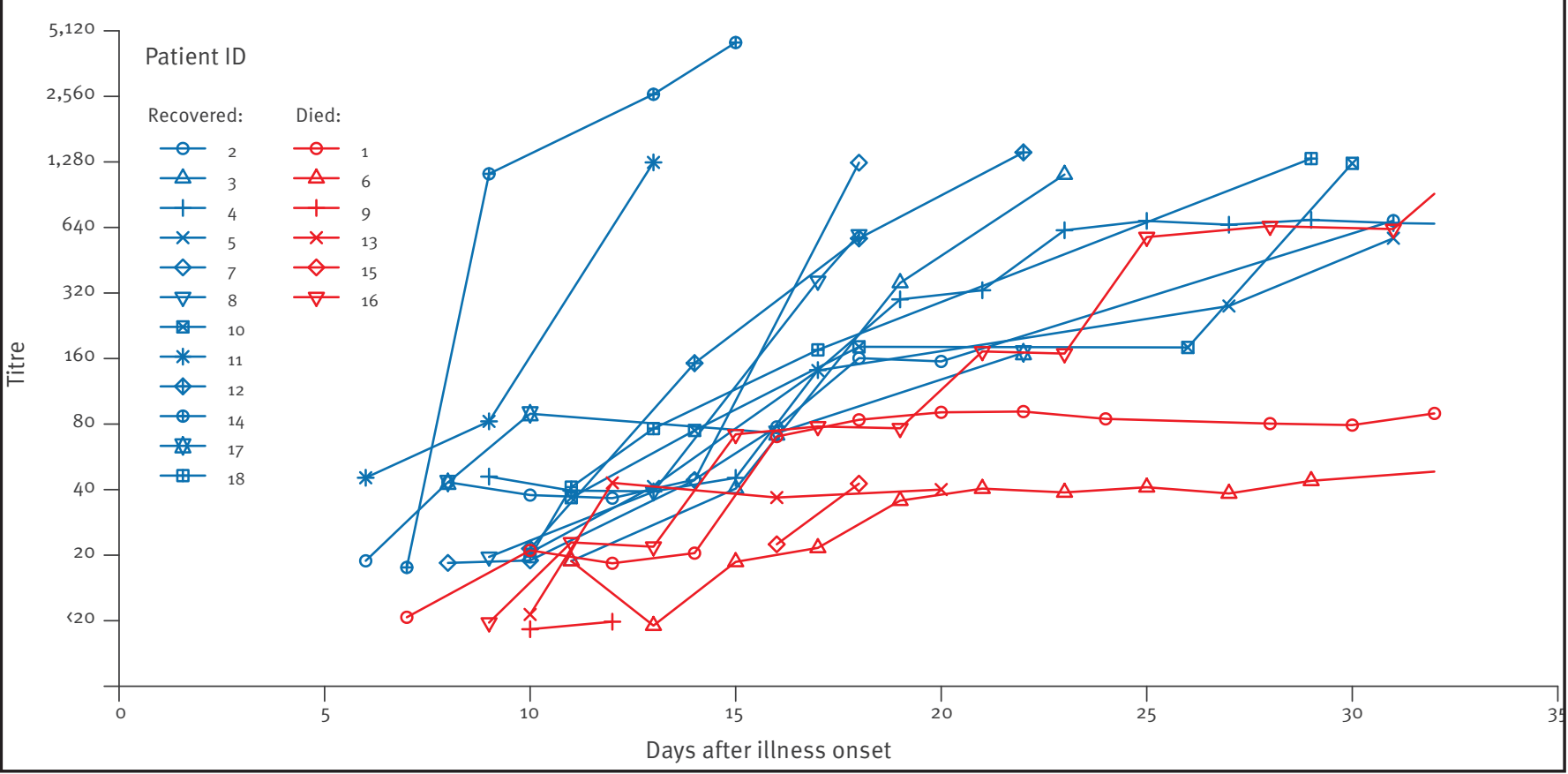

Serum samples were collected from all 18 influenza $A\left(\mathrm{H}_{7} \mathrm{~N} 9\right)$-infected patients. For each patient, two to seven serial serum samples at intervals of three to four days were collected after their admission to our center. The population level kinetics of both (A) HI and (B) neutralisation antibody responses of each individual patient are shown over time. HI titres were not significantly different between survivors and fatal cases at eight to 10 days $(p=0.126)$ and at 11 to 14 days $(p=0.390)$ after illness onset. 
TABLE 1

Viral loads and clinical outcomes in influenza A (H7N9)-infected patients, China, 2013 (n=18)

\begin{tabular}{|c|c|c|c|c|c|c|c|c|}
\hline & \multirow[b]{2}{*}{$\begin{array}{l}\text { Patient } \\
\text { number }\end{array}$} & \multirow[b]{2}{*}{ Sex } & \multirow[b]{2}{*}{ Age } & \multirow[b]{2}{*}{$\begin{array}{l}\text { Underlying medical } \\
\text { disorders }\end{array}$} & \multicolumn{2}{|c|}{$\begin{array}{c}\text { Time between onset of symptoms } \\
\text { and }\end{array}$} & \multirow{2}{*}{$\begin{array}{l}\text { Initial viral } \\
\text { loads } \\
\text { (copies } / \mathrm{mL} \text { ) }\end{array}$} & \multirow{2}{*}{$\begin{array}{c}\text { Clinical } \\
\text { outcome } \\
\text { Discharged } \\
\text { after days } \\
\text { of onset or } \\
\text { death }\end{array}$} \\
\hline & & & & & $\begin{array}{l}\text { the initiation } \\
\text { of oseltamivir } \\
\text { treatment } \\
\text { (days) }\end{array}$ & $\begin{array}{l}\text { first treatment with } \\
\text { methylprednisolone } \\
\text { (days) }\end{array}$ & & \\
\hline \multirow{12}{*}{$\begin{array}{l}\text { Group A: } \\
\text { recovered }\end{array}$} & 11 & M & 53 & None & 5 & 5 & $6.59 \times 10^{2}$ & 14 \\
\hline & 14 & M & 47 & None & 5 & 5 & $9.30 \times 10^{3}$ & 17 \\
\hline & 7 & M & 68 & Hypertension II & 6 & No & $1.29 \times 10^{3}$ & 18 \\
\hline & 8 & M & 65 & Hypertension, urethritis & 4 & No & $3.49 \times 10^{2}$ & 18 \\
\hline & 17 & $\mathrm{~F}$ & 74 & $\begin{array}{l}\text { Hypertension III, coronary } \\
\text { heart disease (NYHA IV), } \\
\text { diabetes II, cholecystitis }\end{array}$ & 8 & No & $5.11 \times 10^{3}$ & 21 \\
\hline & 12 & M & 74 & None & 8 & 12 & $3.68 \times 10^{2}$ & 22 \\
\hline & 2 & $\mathrm{~F}$ & 81 & Arrhythmia & 5 & 6 & $3.08 \times 10^{3}$ & 23 \\
\hline & 3 & M & 67 & None & 5 & 4 & $4.24 \times 10^{3}$ & 23 \\
\hline & 18 & M & 67 & Diabetes II & 11 & 9 & $3.86 \times 10^{2}$ & 24 \\
\hline & 10 & $M$ & 78 & Hypertension II & 11 & 15 & $2.28 \times 10^{2}$ & 31 \\
\hline & 5 & $\mathrm{~F}$ & 75 & $\begin{array}{c}\text { Hypertension II, coronary } \\
\text { heart disease (NYHA IV), } \\
\text { diabetes }\end{array}$ & 8 & 9 & $1.13 \times 10^{3}$ & 33 \\
\hline & 4 & M & 62 & Hypertension & 9 & 5 & $5.70 \times 10^{5}$ & 35 \\
\hline \multirow{5}{*}{$\begin{array}{l}\text { Group Ba: } \\
\text { died }\end{array}$} & 16 & $\mathrm{~F}$ & 79 & $\begin{array}{l}\text { Arrhythmia, coronary } \\
\text { heart disease (NYHA } \\
\text { IV), chronic bronchitis. } \\
\text { primary biliary cirrhosis }\end{array}$ & 6 & 6 & $5.65 \times 10^{4}$ & Death \\
\hline & 1 & $M$ & 56 & None & 3 & 7 & $2.67 \times 10^{2}$ & Death \\
\hline & 6 & M & 58 & Hypertension & 9 & 8 & Negative & Death \\
\hline & 13 & M & 88 & $\begin{array}{c}\text { Hypertension III, coronary } \\
\text { heart disease (NYHA } \\
\text { IV), diabetes II, chronic } \\
\text { bronchitis } \\
\end{array}$ & 7 & 8 & $4.06 \times 10^{4}$ & Death \\
\hline & 15 & M & 80 & None & 7 & 7 & $5.8 \times 10^{3}$ & Death \\
\hline & 9 & M & 74 & $\begin{array}{c}\text { Coronary heart disease } \\
\text { (NYHA III) }\end{array}$ & 6 & 6 & Negative & Death \\
\hline
\end{tabular}

F: female; M: male; NYHA: New York Heart Association Functional Classification.

The virus isolates in patients 13 and 1 developed the Arg292Lys mutation in the neuraminidase protein, which is known to confer resistance to oseltamivir.

Patients are listed by date of discharge from our hospital.

statistically significant $(p=0.108)$. Only age and time until oseltamivir treatment remained significant in the multivariate analysis (Table 3 ).

To specifically examine whether use of methyl prednisolone had an impact on antibody responses, we fitted a linear mixed model including 'initiation of methylprednisolone treatment less than eight days after disease onset' as a variable to predict trends in $\mathrm{HI}$ and Nab titres. Adjusted for age and sex, receiving methylprednisolone treatment within eight days did not have a significant influence on $\mathrm{HI}$ and $\mathrm{Nab}$ titres.

\section{Discussion}

The kinetics of the antibody responses in human $\mathrm{A}\left(\mathrm{H}_{7} \mathrm{~N} 9\right)$ virus infections remain ill defined. Such data are important for serodiagnostic purposes as well as for the interpretation of seroepidemiological studies. Our findings indicate that influenza $\mathrm{A}\left(\mathrm{H}_{7} \mathrm{~N} 9\right)$ infections are associated with generally robust $\mathrm{HI}$ antibody responses and, with one exception (Patient 9, a patient who died), Nab antibody responses. Therefore, serodiagnosis of hospitalised patients should not pose a major challenge, unlike human $\mathrm{H}_{7} \mathrm{~N}_{7}$ infections in the Netherlands in 2003 [9]. It is relevant to note that 
Association of different factors with clinical outcomes in influenza A (H7N9)-infected patients, China, 2013 (n=18)

\begin{tabular}{|c|c|c|c|c|c|c|}
\hline \multirow{2}{*}{ Variables } & \multirow{2}{*}{$\begin{array}{c}\text { Discharge } \\
\text { n (\%) }\end{array}$} & \multirow{2}{*}{$\begin{array}{l}\text { Death } \\
\mathrm{n}(\%)\end{array}$} & \multicolumn{2}{|c|}{ Univariate analysis } & \multicolumn{2}{|c|}{ Multivariate analysis } \\
\hline & & & $\mathrm{OR}^{\mathrm{a}}(95 \% \mathrm{Cl})$ & $\mathrm{p}$ value & $\mathrm{OR}^{\mathrm{a}}(95 \% \mathrm{Cl})$ & $\mathrm{p}$ value \\
\hline \multicolumn{7}{|l|}{ Sex } \\
\hline Male & $9(64.3)$ & $5(35.7)$ & 1 & - & - & - \\
\hline Female & $3(75.0)$ & $1(25.0)$ & $1.62 \quad(0.096-105)$ & 1 & - & - \\
\hline \multicolumn{7}{|l|}{ Age } \\
\hline$<75$ years & $9(75.0)$ & $3(25.0)$ & 1 & - & - & - \\
\hline$\geq 75$ years & $3(50.0)$ & $3(50.0)$ & $0.344 \quad(0.027-4.17)$ & 0.356 & - & - \\
\hline \multicolumn{7}{|l|}{ Medical disorders } \\
\hline No & $4(44.7)$ & $2(33.3)$ & 1 & - & - & - \\
\hline Yes & $8(66.7)$ & $4(33 \cdot 3)$ & $1.00 \quad(0.064-11.5)$ & 1 & - & - \\
\hline \multicolumn{7}{|c|}{ Initiation of oseltamivir treatment } \\
\hline$<8$ days & $6(54.5)$ & $5(45 \cdot 5)$ & 1 & - & - & - \\
\hline$\geq 8$ days & $6(85.7)$ & $1(14.3)$ & $4.59(0.346-275)$ & 0.316 & - & - \\
\hline \multicolumn{7}{|c|}{ Initiation of methylprednisolone treatment } \\
\hline$<8$ days & $5(55.6)$ & $4(44.4)$ & 1 & - & - & - \\
\hline$\geq 8$ days & $7(77.8)$ & $2(22.2)$ & $2.64(0.253-40.5)$ & 0.620 & - & - \\
\hline \multicolumn{7}{|l|}{ First viral load } \\
\hline$\ll 1,000$ copies $/ \mathrm{mL}$ & $5(62.5)$ & $3(37.5)$ & 1 & - & - & - \\
\hline$\geq 1,000$ copies $/ \mathrm{mL}$ & $7(70.0)$ & $3(30.0)$ & $1.37(0.126-15.2)$ & 1 & - & - \\
\hline \multicolumn{7}{|c|}{ Nab titre reaches $1: 640$} \\
\hline No & $1(16.7)$ & $5(83.3)$ & 1 & - & 1 & - \\
\hline Yes & $11(91.7)$ & $1(8.3)$ & $35.4(1.99-2740)$ & 0.004 & $16.9(2.19-220)$ & 0.006 \\
\hline \multicolumn{7}{|c|}{ Nab titre reaches $1: 40$} \\
\hline$\leq 14$ days & $11(84.6)$ & $2(15.4)$ & 1 & - & 1 & - \\
\hline$>14$ days & $1(20.0)$ & $4(80.0)$ & $\begin{array}{c}0.0587 \\
(0.000858-0.941)\end{array}$ & 0.022 & $\begin{array}{c}0.0361 \\
(0.000-0.519)\end{array}$ & 0.011 \\
\hline \multicolumn{7}{|c|}{$\mathrm{HI}$ titre reaches $1: 40^{\mathrm{b}}$} \\
\hline$\leq 10$ days & $5(62.5)$ & $3(37.5)$ & 1 & - & - & - \\
\hline$>10$ days & $7(70.0)$ & $3(30.0)$ & $1.37(0.126-15.2)$ & 1 & - & - \\
\hline
\end{tabular}

-, not relevant; $\mathrm{Cl}$ : confidence interval; HI: haemagglutination inhibition; Nab: pseudotype neutralisation antibody; OR: odds ratio.

a $O R>1$ indicates 'preferring recovery'. Multivariate analyses were performed by examining whether Nab titres reached 1:640 or 1:40 within 14 days in a model with co-factors of age and sex.

b Missing $\mathrm{HI}$ titres within 10 days were imputed conservatively in such a way that would attenuate the results toward the null hypothesis.

nearly all diagnosed $\mathrm{H}_{7} \mathrm{~N}$ 9-infected patients had more severe disease (namely pneumonia) compared with the outbreak in the Netherlands, where diagnosed patients had mainly mild conjunctivitis or influenza-like illness. Thus, one cannot be certain that milder or asymptomatic influenza $\mathrm{A}\left(\mathrm{H}_{7} \mathrm{~N} 9\right)$ infections would manifest comparably robust serological responses. In addition, this has to be kept in mind when interpreting community-wide seroepidemiological studies. It would be interesting to have serological data from family members and contacts of our patients. Unfortunately, such a follow-up study was not conducted.
The progression of influenza $A\left(\mathrm{H}_{7} \mathrm{~N} 9\right)$ disease was observed to be slower than of influenza $A\left(\mathrm{H}_{5} \mathrm{~N}_{1}\right)$ disease, the median time from hospitalisation to death being 12.0 days and 5.7 days, respectively [13]. We hypothesised that the prolonged disease course of $\mathrm{H}_{7} \mathrm{~N}_{9}$ compared with $\mathrm{H}_{5} \mathrm{~N}_{1}$ influenza (and SARS-CoV) infection is likely to imply that there is more opportunity for the adaptive immune response to contribute to recovery and survival. Therefore, we examined the antibody responses with $\mathrm{HI}$ and $\mathrm{Nab}$ assays in influenza $\mathrm{A}\left(\mathrm{H}_{7} \mathrm{~N} 9\right)$-infected patients admitted into our clinical center. We evaluated the correlation between the kinetics of $\mathrm{HI}$ and $\mathrm{Nab}$ antibody responses and clinical 
TABLE 3

The association of different factors with time to recovery for recovered patients

\begin{tabular}{|c|c|c|c|c|c|}
\hline \multirow{2}{*}{ Variables } & \multirow{2}{*}{$\begin{array}{l}\text { Median time } \\
\text { to recovery } \\
\text { (days) }\end{array}$} & \multicolumn{2}{|c|}{ Univariate analysis } & \multicolumn{2}{|c|}{ Multivariate analysis } \\
\hline & & $\mathrm{AF}^{\mathrm{a}}(95 \% \mathrm{Cl})$ & $p$ value & $\mathrm{AF}^{\mathrm{b}}(95 \% \mathrm{Cl})$ & $\mathrm{p}$ value \\
\hline \multicolumn{6}{|l|}{ Sex } \\
\hline Male & 22.0 & 1 & & 1 & \\
\hline Female & 23.0 & $1.17(0.831-1.64)$ & 0.374 & $0.893(0.709-1.12)$ & 0.332 \\
\hline \multicolumn{6}{|l|}{ Age } \\
\hline$<75$ years & 21.0 & 1 & & 1 & \\
\hline$\geq 75$ years & 31.0 & $1.39(1.03-1.86)$ & 0.031 & $1.32(1.05-1.66)$ & 0.019 \\
\hline \multicolumn{6}{|l|}{ Medical disorders } \\
\hline No & 19.5 & 1 & & 1 & \\
\hline Yes & 23.5 & $1.32(0.999-1.75)$ & 0.051 & $0.994(0.795-1.24)$ & 0.960 \\
\hline \multicolumn{6}{|l|}{ Initiation of oseltamivir treatment } \\
\hline$<8$ days & 18.0 & 1 & & 1 & \\
\hline$\geq 8$ days & 27.5 & $1.46(1.18-1.81)$ & $<0.001$ & $1.31(1.11-1.56)$ & 0.002 \\
\hline \multicolumn{6}{|c|}{ Initiation of methylprednisolone treatment } \\
\hline$<8$ days & 23.0 & 1 & & - & - \\
\hline$\geq 8$ days & 22.0 & $1.09(0.806-1.48)$ & 0.575 & - & - \\
\hline \multicolumn{6}{|l|}{ First viral load } \\
\hline$<1000$ & 22.0 & 1 & & - & - \\
\hline$\geq 1000$ & 23.0 & $1.12(0.826-1.51)$ & 0.476 & - & - \\
\hline \multicolumn{6}{|l|}{ Nab titre reaches $1: 640$} \\
\hline 221 days or not reaching $1: 640$ & 23.5 & 1 & & - & - \\
\hline $15-21$ days & 20.0 & $0.878(0.681-1.13)$ & 0.312 & $0.996(0.803-1.23)$ & 0.968 \\
\hline$\leq 14$ days & 15.5 & $0.606(0.440-0.835)$ & 0.002 & $0.784(0.584-1.05)$ & 0.108 \\
\hline \multicolumn{6}{|l|}{ Nab titre reaches $1: 40$} \\
\hline$\leq 14$ days & 22.0 & 1 & & - & - \\
\hline 214 days & 23.0 & $1.03(0.595-1.78)$ & 0.922 & - & - \\
\hline \multicolumn{6}{|l|}{ HI titre reaches $1: 40^{b}$} \\
\hline$\leq 10$ days & 24.0 & 1 & & - & - \\
\hline$>10$ days & 22.0 & $0.88(0.655-1.191)$ & 0.415 & - & - \\
\hline
\end{tabular}

-, not relevant; $\mathrm{Cl}$ : confidence interval; HI: haemagglutination inhibition; Nab: pseudotype neutralisation antibody; AF: acceleration factor.

a AF 1 indicates reduction in time from illness onset to recovery. Multivariate analyses were performed by examining medical disorder, initiation of oseltamivir treatment after eight days and time to reach Nab titres 1:640, in a model with co-factors of age and sex.

b Missing HI titres within 10 days were imputed conservatively in such a way that would attenuate the results toward the null hypothesis.

disease outcome of survival or death. Strikingly, we observed that the early and rapid induction of $\mathrm{Nab}$ significantly correlated with the rapid recovery from illness. The two groups of patients did not differ in initial $\mathrm{Nab}$ antibody titres, but the rate of antibody titre increase was approximately 10 -fold faster per 15 days in survivors than in fatal cases $(p=0.007)$. In contrast, no significant association was observed between $\mathrm{HI}$ titres and clinical outcomes. While the $\mathrm{HI}$ test only detects antibodies against the receptor-binding domain of the globular head of the haemagglutinin, neutralisation could be conferred by antibodies against the stalk of the haemagglutinin as well as the neuraminidase. Therefore, it is possible that neutralisation and $\mathrm{HI}$ antibodies may differ in their capacity to control influenza infection, and Nab may represent a better early surrogate marker for recovery from $\mathrm{H}_{7} \mathrm{~N}_{9}$ influenza disease.

In those who survived the infection, reaching Nab titres of $\geq 1: 640$ within 14 days of illness was associated with a trend toward faster recovery. Interestingly, while age and time to oseltamivir treatment were not significantly associated with survival in the group overall, they were associated with faster recovery in the survivors. This 
difference may be related to the finding that emergence of oseltamivir resistance was associated with adverse clinical outcome in at least two of our patients with fatal outcome [8]. Another recent study reported association between faster serological responses and survival in $\mathrm{H} 7 \mathrm{~N} 9$ influenza patients, although it did not account for censoring due to time of testing and death, nor investigate the role of other confounding factors such as corticosteroid therapy or antiviral therapy [17].

Antibodies use different mechanisms to contain virus infection, including direct neutralisation of virus entry, antibody-dependent cytotoxic responses and directing presentation of virus-antibody complexes to antigenpresenting cells [14]. It is also possible that the early development of $\mathrm{Nab}$ antibodies and the rapid involvement of $\mathrm{Nab}$ antibodies in responding to influenza virus infection may alter the innate immune response and thereby result in a milder disease course. Previous reports have demonstrated that severe clinical disease in highly pathogenic avian influenza infection was usually associated with skewed innate immune responses which were characterised by the production of more pro-inflammatory cytokines and less type I interferon, whereas a mild influenza disease course was associated with a balanced type I interferon and inflammatory response $[15,16]$. An alternative explanation is that the antibody responses are a surrogate marker for cellmediated immune responses.

In summary, our data demonstrate that the haemagglutinin of the $2013 \mathrm{~A}\left(\mathrm{H}_{7} \mathrm{~N} 9\right)$ influenza virus is immunogenic and capable of rapidly eliciting robust $\mathrm{HI}$ and $\mathrm{Nab}$ antibody responses. The kinetics of the Nab response are correlated with clinical outcome. Cause and effect cannot yet be established because antibody responses may be a confounding factor associated with other protective determinants of clinical outcome. Convalescent plasma therapy has previously been shown to reduce mortality in patients in intensive care with pandemic $\mathrm{H}_{1} \mathrm{~N}_{1}$ influenza [18]. Thus, our data may indicate that early passive antibody therapy may be beneficial to clinical outcome, especially in those who fail to mount rapid Nab antibody responses.

\section{Acknowledgements}

This work was supported by the National Grand Program on Key Infectious Disease Control (2012ZX10001-006, 2013ZX10001-002), the China Ministry of Health, and by the 973 National Key Basic Research Project (2012CB519005), the Ministry of Science and Technology of PRC. EHYL, JTW, CYLL and JSMP were supported from an Area of Excellence Scheme of the University Grants Committee (Grant AoE/M-12/96), Hong Kong Special Administrative Region.

\section{Conflict of interest}

None declared.
Authors' contributions

$A Z, Y H, D T, E L, Y W$ and $X L$ conducted the study and analysed data, ZS, YD, XZ, JZ, MB, MZ, SY, JS, ZZ, YWH, LC, CL and JW processed samples and prepared sera samples., $X Y Z$ and ZYZ coordinated the study and provided samples, MP and JX conceived and designed the study, analysed data and wrote the manuscript.

\section{References}

1. Liu Q, Lu L, Sun Z, Chen GW, Wen Y, Jiang S. Genomic signature and protein sequence analysis of a novel influenza $A\left(\mathrm{H}_{7} \mathrm{~N} 9\right)$ virus that causes an outbreak in humans in China. Microbes Infect. 2013;15(6-7):432-9.

http://dx.doi.org/10.1016/j.micinf.2013.04.004 PMid:23628410

2. Yang $F$, Wang J, Jiang L, Jin J, Shao L, Zhang Y, et al. A fatal case caused by novel $\mathrm{H}_{7} \mathrm{~N} 9$ avian influenza $\mathrm{A}$ virus in China. Emerging Microbes and Infections. 2013;2:e19. http://dx.doi. org/10.1038/emi.2013.22 PMCid:PMC3636593

3. Gao R, Cao B, Hu Y, Feng Z, Wang D, Hu W, et al. Human Infection with a Novel Avian-Origin Influenza A ( $\left.\mathrm{H}_{7} \mathrm{Ng}\right)$ Virus. N Engl J Med. 2013;368(20):1888-97. http://dx.doi.org/10.1056/ NEJMoa1304459 PMid:23577628

4. Li Q, Zhou L, Zhou M, Chen Z, Li F, Wu H, et al. Preliminary Report: Epidemiology of the Avian Influenza A (H7N9) Outbreak in China. N Engl J Med. 2013 Apr 24. [Epub ahead of print]. http://dx.doi.org/10.1056/NEJMoa1304617 PMCid:PMC3652256

5. World Health Organization (WHO). Number of confirmed human cases of avian influenza $\mathrm{A}\left(\mathrm{H}_{7} \mathrm{~N} 9\right)$ reported to WHO. Geneva: WHO. [Accessed 3 Oct 2013]. Available from: http://www.who. int/influenza/human_animal_interface/influenza_h7ng/10u_ ReportWebH7N9Number.pdf

6. Lam TT, Wang J, Shen Y, Zhou B, Duan L, Cheung CL, et al. The genesis and source of the $\mathrm{H}_{7} \mathrm{~N} 9$ influenza viruses causing human infections in China. Nature. 2013;502(7470):241-4. http://dx.doi.org/10.1038/nature12515 PMid:23965623

7. Gao HN, Lu HZ, Cao B, Du B, Shang H, Gan JH, et al. Clinical findings in 111 cases of influenza $\mathrm{A}(\mathrm{H} 7 \mathrm{Ng}$ ) virus infection. $\mathrm{N}$ Engl J Med. 2013;368(24):2277-85. http://dx.doi.org/10.1056/ NEJMoa1305584 PMid:23697469

8. Hu Y, Lu S, Song Z, Wang W, Hao P, Li J, et al. Association between adverse clinical outcome in human disease caused by novel influenza A H7N9 virus and sustained viral shedding and emergence of antiviral resistance. Lancet. 2013;381:(9885):2273-9.

http://dx.doi.org/10.1016/So140-6736(13)61125-3

9. Meijer A, Bosman A, van de Kamp EE, Wilbrink B, Du Ry van Beest Holle M, Koopmans M. Measurement of antibodies to avian influenza virus $\mathrm{A}\left(\mathrm{H}_{7} \mathrm{~N}_{7}\right)$ in humans by hemagglutination inhibition test. J Virol Methods. 2006;132(1-2):113-20. http://dx.doi.org/10.1016/j.jviromet.2005.10.001 PMid:16271401

10. Qiu C, Huang Y, Zhang A, Di Tian, Wan Y, Xiaoling Zhang $X$, et al. Safe pseudovirus-based assay for neutralization antibodies against influenza $\mathrm{A}\left(\mathrm{H}_{7} \mathrm{~N} 9\right)$ virus. Emerg Infect Dis. 2013;19(10):1685-7. http://dx.doi.org/10.3201/eid1910.130728 PMid:24047684 PMCid:PMC3810762

11. Garcia JM, Lagarde N, Ma ES, de Jong MD, Peiris JS. Optimization and evaluation of an influenza $\mathrm{A}\left(\mathrm{H}_{5}\right)$ pseudotyped lentiviral particle-based serological assay. J Clin Virol. 2010;47(1):29-33. http://dx.doi.org/10.1016/j. jcv.2009.10.009 PMid:19897409

12. Centers for Disease Control and Prevention (CDC). Modified hemagglutination inhibition ( $\mathrm{HI}$ ) assay using horse RBCs for serologic detection of antibodoes to $\mathrm{H}_{7}$ subtype avian influenza virus in human sera. Atlanta: CDC. Version 1. [Accessed 10 Dec 2013]. Available from: http://consise. tghn.org/site_media/media/articles/160713_Modified Hemagglutination_Inhibition_Assay_Using_Horse_RBC̄s.pdf.

13. Cowling BJ, Jin L, Lau EH, Liao Q, Wu P, Jiang $H$, et al. Comparative epidemiology of human infections with avian influenza $\mathrm{A} \mathrm{H}_{7} \mathrm{~N}_{9}$ and $\mathrm{H}_{5} \mathrm{~N}_{1}$ viruses in China: a populationbased study of laboratory-confirmed cases. Lancet. 2013;382(9887):129-37. http://dx.doi.org/10.1016/S0140-6736(13)61171-X

14. Manca F, Fenoglio D, Li Pira G, Kunkl A, Celada F. Effect of antigen/antibody ratio on macrophage uptake, processing, and presentation to T cells of antigen complexed with polyclonal antibodies. J Exp Med. 1991;173(1):37-48. http://dx.doi. org/10.1084/jem.173.1.37 PMid:1985125

15. Baskin CR, Bielefeldt-Ohmann H, Tumpey TM, Sabourin PJ, Long JP, Garcia-Sastre A, et al. Early and sustained innate 
immune response defines pathology and death in nonhuman primates infected by highly pathogenic influenza virus.

Proc Natl Acad Sci U S A. 2009;106(9):3455-60. http://

dx.doi.org/10.1073/pnas.0813234106 PMid:19218453

PMCid:PMC2642661

16. Szretter KJ, Gangappa S, Belser JA, Zeng H, Chen H, Matsuoka $\mathrm{Y}$, et al. Early control of $\mathrm{H}_{5} \mathrm{~N}_{1}$ influenza virus replication by the type I interferon response in mice. J Virol. 2009;83(11):5825 34. http://dx.doi.org/10.1128/JVI.02144-08 PMid:19297490 PMCid:PMC2681972

17. Yang S, Chen Y, Cui D, Yao H, Lou J, Huo Z, et al. Avian-Origin Influenza $\mathrm{A}\left(\mathrm{H}_{7} \mathrm{~N}\right.$ 9) Infection in Influenza $\mathrm{A}\left(\mathrm{H}_{7} \mathrm{~N} 9\right)$-Affected Areas of China: A Serological Study. J Infect Dis. 2013 Sep 18. [Epub ahead of print]. http://dx.doi.org/10.1093/infdis/jit430

18. Hung IF, To KK, Lee CK, Lee KL, Chan K, Yan WW, et al.

Convalescent plasma treatment reduced mortality in patients with severe pandemic influenza $A\left(\mathrm{H}_{1} \mathrm{~N}_{1}\right) 2009$ virus infection. Clin Infect Dis. 2011;52(4):447-56. http://dx.doi.org/10.1093/ cid/ciq106 PMid:21248066 